\title{
ENSAIO DE IMAGENS - CIDADES: OLHARES DE LEITORA ${ }^{1}$
}

\author{
FERNANDES, Andrea da Paixão²
}

Ao me propor a escrever uma resenha do livro Ensaio de Imagens - cidades, recém lançado, organizado por Gianne Chagastelles, me via conversando com modos de ver cidades brasileiras, dentre elas, a nossa: o Rio de Janeiro. Encantei-me com as formas que cada autora - sim, o livro foi escrito por mulheres - olha e lê a cidade ou a parte da cidade escoIhida para escrever. Permito-me, portanto, tecer uma resenha que dialogue com as entranhas deste livro e, assim, a compartilhar uma experiência de formação.

São textos que fazem referência a estudos sobre cidades e que partem do recurso imagético como possibilidade para o desbravamento da cidade escolhida (ou de parte dela). A diversidade de enfoques e de olhares permite que este livro se faça plural e um convite à leitura, de forma leve e criativa, mas sem perder de vista a profundidade das pesquisas realizadas para que cada artigo se construísse. São artigos oriundos de pesquisas acadêmicas, mas também de ensaios de observações de lugares recém-descobertos pelas lentes de quem escreve. A cidade, como bem retrata a organizadora do livro, "é pensada como espaço - de sociabilidades, de encontros, de circulação - que é apropriado pelas pessoas". E é assim que fui me vendo e conversando com cada um dos textos. Busca-se perceber e compreender a cidade em sua plenitude: como lugares diversos em contextos, enfoques, práticas, organização. A cidade é entendida também pelo viés da comunicação e informação, sendo "atravessada por representações e símbolos que traduzem hegemonias e contra-hegemonias" (CHAGASTELLES, 2016, p. 9).

O livro se estrutura em quatropartes. A primeira apresenta maior relação com a história cultural e ao trabalho com fotografia dialogando com outras imagens: ilustrações, charges, por exemplo. A segunda permite ao leitor se enveredar pela discussão das diferenças sociais e políticas manifestadas na cidade. A terceira parte busca dialogar com as artes visuais, ao passo que a cultura da moda compõe o último ensaio.

O texto de Gianne Chagastelles, "Um rio frenético - o ambiente urbano e o lazer na era Vargas", apresenta as diferentes formas de lazer e de sociabilidade no Rio de Janeiro Varguista, dialogando com entrevistas de pessoas que viveram situações de lazer no período e imagens - charges de J. Carlos, fotografias de álbuns de família e de revistas ilustradas da época. Gianne possibilita ao leitor viajar pelo Rio Antigo, por seu burburinho, suas atividades de lazer e, por que não, de consumo, seu ritmo frenético. Problematiza temas que circulam na cidade, além de um novo modo de vida e de uma nova cidade que resultou das transformações advindas com a modernidade. Traz memórias de Copacabana e do centro da cidade art décoe de um Rio que foi, pouco a pouco, se modernizando e, assim, se expandindo.A cidade se apresenta como local de circulação, com seus fluxos e consumo e foi se tornando, cada vez mais, em uma metrópole de ritmo intenso.

\footnotetext{
${ }^{1}$ CHAGASTELLES, Gianne (org). Ensaio de imagens - cidades. Rio de Janeiro: Editora Multifoco, 2016, 384p.

${ }^{2}$ Professora Adjunta da Universidade do Estado do Rio de Janeiro - Instituto de Aplicação Fernando Rodrigues da Silveira (CAp-UERJ). Email: andreaf@uerj.br
} 
Em "As margens da linha do trem - representações imagéticas do subúrbio carioca", Andrea Vizzotto traz as reflexões e discussões sobre o que é o subúrbio na cidade a partir de imagens fotografadas por Marcelo Feitosa e de versos de Chico Buarque. O ensaio de Andrea, complementando o de Gianne, apresenta um "outro" Rio de Janeiro, que transcende o Centro e a Zona Sul e traz para a cena o subúrbio ainda não modernizado, mas rural. Assim ela dialoga com as mudanças ocorridas na cidade a partir de olhares de lugares proletários que correm paralelos à linha ferroviária no Rio de Janeiro.

Indo a uma cidade de outro estado, em "Belo Horizonte através das revistas ilustradas da primeira metade do século XX", Carla Corradi se apropria das revistas ilustradas para descrever as transformações da cidade de belo Horizonte a partir dos movimentos de circulação da sociedade na primeira metade do século XX e da representação da cidade apresentada pelas revistas analisadas. Tradição e modernidade de Belo Horizonte estão presentes em seu ensaio por meio da relação entre a cidade e a imprensa. Observa, ainda, a segregação social manifestada nas revistas em tela, que valorizavam os movimentos mais elitizados da sociedade em lugar de reservar espaço às formas de viver na periferia belorizontina.

Karina Pinheiro nos permite conhecer por meio de "O olhar artístico do PCB - favelas cariocas no Tribuna Popular (1945-1947)" como imagens das favelas cariocas se apresentam no jornal Tribuna Popular. Aborda o processo de criação e de expansão das favelas, considerando que na década de 1940 houve um crescimento populacional no Rio de Janeiro, provocando o crescimento das favelas nas zonas central e sul da capital fluminense, pois essa era uma demanda necessária para que esses novos moradores pudessem morar em lugares próximos aos seus locais de trabalho, ainda que em situações de moradias precarizadas. Além disso, o ensaio provoca o leitor a refletir sobre a exclusão dessas famílias pelo poder público, com a remoção de favelas de lugares que foram se elitizando por meio da expansão imobiliária. A relação das ilustrações com a atuação do PCB e do poder público na vida dos moradores faz parte da busca de possíveis sentidos das representações da cidade.

"Movimento estudantil - transição nas imagens da cidade", de Gislene Lacerda, também convida o leitor a se enveredar pelo cenário político de esquerda. Mas aqui o olhar é sobre a cidade de São Paulo e as mobilizações da segunda metade dos anos 1970, mas especificamente 1977, por meio das lentes de fotógrafos de jornais de grande circulação e que procuraram captar modos de ver a cidade no contexto da transição democrática brasileira. Do silenciamento das vozes dos anos 1960 ao rompimento com o silêncio e a retomada das ruas em 1977 estão retratados no texto a partir das lentes desses fotógrafos.

O ensaio "Disputas por espaço na paisagem - experiências e trajetórias de artistas de rua na história recente de Florianópolis", de Débora Daniel traz para o diálogo a relação de poder existente entre grupos sociais distintos e o significado do que é arte pública. Que espaços na paisagem de Florianópolis os artistas de rua ocupam? Essa é uma questão central no ensaio que problematiza também a relação que a gestão municipal estabelece com esses artistas, a exemplo dos malabaristas que foram impedidos de se apresentarem nos sinais de trânsito.

Abrindo a terceira parte do livro, Daniela Name traz em "Sobre livros e labirintos arte e narrativa nas obras públicas e coletivas de Amelia Toledo, Hélio Oiticiae Lygia Pape" estuda as obras públicas e coletivas no âmbito da cidade, dialogando sobre como as obras de arte desses artistas interferem na cidade e, segundo a autora, se relacionam com a noção de narrativa e literatura. A noção de biblioteca e a capacidade de organizar as informações em camadas também se manifestam no ensaio, bem como espirais e labirintos, tão presentes nas obras desses três autores. "Como as bibliotecas, labirintos não são apenas lugares, 
são experiências de percepção e de conjugação de tempos" (NAME, 2016, p. 271). A análise desenvolvida por Daniela Name considera, por exemplo, o trabalho de Amélia Toledo na Estação Cardeal Arcoverde do metrô, em Copacabana.

Moema Alves, autora de "Viagens de artistas - o trânsito das pinturas de paisagem no início do século XX", dialoga com as viagens realizadas por pintores que buscam problematizar a cidade a partir das imagens e do seu trânsito. A diversidade que compõe a cidade está presente e são ressaltadas as que representam as cidades e o urbano. Destaca os movimentos de reconhecimento de uma arte que represente o Brasil e os fluxos de idas e vindas nos quais se colocam os pintores para divulgarem seus trabalhos. Nessas viagens, outras obras surgem e, com isso, a paisagem como estilo de pintura.

A cultura da moda está presente no ensaio de autoria de Christiane Arcuri intitulado "Fluxos visuais - as narrativas entre modas e modos dos cariocas de Copacabana". Os visuais de Copacabana e as narrativas imagéticas presentes no bairro fazem parte da tessitura das (entre)linhas de seu texto. Nesse contexto, as modas das vitrines e os modos comportamentais dos moradores de Copacabana se manifestam pelos olhares e mãos dessa recente moradora (ou turista) do bairro. Christiane Arcuri analisa, ainda, as vitrines de galerias e lojas que vendem produtos de souvenirs, mas sem perder de vista as paisagens que ajudam a representar o que é ser carioca. Para a autora, a moda se insere em um sistema de representações ou em um sistema de linguagem que permitem decifrar significados e interpretações que se ancoram na subjetividade.

Volto ao começo e convido o leitor desta resenha a adentrar pelas páginas e viajar por esse Ensaio de Imagens, passeando pelas passagens e também imagens de cidades que, com sua diversidade e modos, contam e encantam a quem os lê. 